\title{
The Challenges of Governing: The State Council in China
}

\author{
Xu Yi-chong and Patrick Weller
}

\begin{abstract}
A B S T R A C T
The Standing Committee of the State Council (SCSC) is the principal government institution in China and is often referred to as the "Chinese Cabinet." This article seeks to explain how the SCSC fulfills two functions that are required in all government executives: coordination and the resolution of disputes. It describes the membership of the SCSC, its supporting structures and its working practices, and identifies the alternative strategies available to the premier. The article challenges two popular accounts of the State Council that underplay its role in Chinese politics by either attributing all authority up to the Politburo of the Chinese Communist Party or downward to the bureaucracies. The article concludes by suggesting a series of nuanced roles that the SCSC plays as it seeks to meet those key challenges of governing that, regardless of regime, all executive governments must face.
\end{abstract}

$\mathrm{T}$ he Standing Committee of the State Council faces the challenges of governing that are common to all governments: how to manage the processes of diagnosis, conciliation, coordination, and implementation. This study applies the insights of core executive studies to examine this central governing institution in China and shows how it coordinates government activities. In doing so, it challenges two popular accounts of the State Council that underplay its role in Chinese politics by either attributing all authority upward to the Politburo of the Chinese Communist Party or downward to the bureaucracies. The oft-repeated maxim that "the Party decides" camouflages two significant issues: who is "the Party," and by what processes and in what forums does it decide? If, as David Lampton suggests, "at each stage of the seemingly endless process of making policy in China, there are struggles-over resources, over power, over ego"1-we need to explain how the SCSC, with its allocated authority and responsibilities and with its predetermined formal and informal procedures, coordinates governmental activities, shapes decisions on policies, oversees their implementation, and, all in all, how it governs. ${ }^{2}$

1. David Lampton, Following the Leader (Berkeley: University of California Press, 2014), 79.

2. This is the argument made by the historical institutionalists. See, e.g., "The Role of Theory in Comparative Politics," World Politics 48, no. 1 (1995): 1-49; Stephen Skowronek, The Politics Presidents Make (Cambridge, MA: Harvard University Press, 1993).

Electronically published May 6, 2016

The China Journal, no. 76. 1324-9347/2016/7601-0001. Copyright 2016 by The Australian National University. All rights reserved. 
We argue that in almost all political systems, the top executive level of governments plays similar roles: to coordinate and to resolve conflicts among bureaucracies, localities, and other organizations. ${ }^{3}$ But we cannot take as a given who has the authority. As R. A. W. Rhodes explained when delineating the core executive concept, we have to look at "all those structures that coordinate policy, rather than privileging an account of the power of one position-holder above that of another." ${ }^{4}$ Yet despite the prominent position the SCSC occupies in governing the country, few observers of China seek to explain how the SCSC works. ${ }^{5}$ It is our modest intention to understand how the Chinese "cabinet" seeks to govern, especially when it takes on the two key functions of governing that all executive bodies must fulfill: "coordination" and "resolution of disputes." In doing so, we need to look beyond the formal positions of the premier, vice premiers or state councillors, or the State Council as a unitary institution, and also focus on the top-level officials whose job is to influence coordination and dispute resolution in or around the State Council.

We argue that governing cannot either be reduced to the parsimonious "the Party governs everything"6 or attributed to the "warlords" of bureau politics. How the government operates needs to be explained, not by focusing on titles or positions but on the roles, resources and, more importantly, the capacities of the individuals involved. We then apply insights from the comparative literature on core executives to explain how the State Council governs, by asking: who does what and who has what resources? We situate the SCSC, with its personal and institutional resources, within China's coordinating and decisionmaking systems. In the conclusion, we again apply insights from the literature on cabinets and the core executive to explain the nuanced range of functions that the SCSC plays within the broader context of China's political system.

\section{WHY THE CORE EXECUTIVE?}

The Chinese governing system is described as one with both extreme centralization and extreme decentralization. Those who emphasize the centralization of

3. Lampton, Following the Leader.

4. R. A. W. Rhodes, "From Prime Ministerial Power to the Core Executive," in Prime Minister, Cabinet and Core Executive, ed. R. A. W. Rhodes and P. Dunleavy (London: Macmillan, 1995), 12.

5. This includes the books on Chinese politics that pay only passing attention to it: when scholars acknowledge that "government power resides with the State Council" or the State Council is "the highest executive body and the centre of state power" (Joseph Fewsmith, China Today, China Tomorrow [New York: Rowman \& Littlefield, 2010], 55; see also Tony Saich, Governance and Politics of China [Hampshire: Palgrave Macmillan, 2nd ed., 2004]; Kenneth Lieberthal, Governing China [New York: Norton, 2004]), they quickly add that policies are decided by the Chinese Communist Party.

6. Changjiang Wang, "Transition from a Revolutionary Party to a Governing Party," in China's Political Development, ed. Kenneth Lieberthal, Cheng Li, and Yu Keping (Washington, DC: Brookings Institution Press, 2014), 79. 
the Chinese government argue that the Party's top leadership sits at the apex of the hierarchies of the Party, China's legislative chambers, the government, and the military. ${ }^{7}$ This emphasis on the supreme Party leadership in deciding everything clearly simplifies the complex political reality in China. For one, within each section of the polity-the Party, the state represented by the National People's Congress, the government embodied in the State Council, and the militarythere is a complex hierarchical structure. Each part has its own functions and role to play in governing. The central role of the Party must be acknowledged, yet the Party is fused within all institutions in China. It is not another key institution of the state. It is inside, above, and around the state institutions. ${ }^{8}$ The Party and the government, nonetheless, have different functions to play. Indeed, the existence of the Party (or the party-state) as the source of all policies does not of itself provide any answer to questions of where ideas come from and which policies will be adopted. Being "the Party" does not determine or govern choices. The party-state itself needs to be explained.

Those who emphasize a decentralized and fragmented Chinese political system see the government as no more than its parts-its principal central bureaucracies and their tentacles in provinces, counties, and local governments. Their bargaining and consensus-building have created as an enduring feature "a protracted, disjointed policy process," as Kenneth Lieberthal and Michel Oksenberg have argued. ${ }^{9}$ This "fragmented authoritarianism" 10 misses the central part of governing-coordination: who coordinates and how do they coordinate? These are the key questions of core executive studies.

The statement that "the Party decides" elides two issues. First, it implies a dichotomy between the Party and government, as though the two are separate in the way that cabinet and civil service are separate or the way the President and Congress in the United States are separate. In practice, the Party and government in China are fused. Two of the seven members of the Politburo's Standing Committee are members of the SCSC; it makes little sense to see them as competing centers of power.

Second, the comment "the Party decides" may camouflage the reality that decisions taken within the government machinery such as the SCSC can all be interpreted as party-state government decisions. But that statement does not help determine how and where issues were identified, what alternative responses were put forward and considered, whose influence was crucial, or how institutional actions were coordinated. As in governments everywhere, the potential sources

7. Robert Lawrence Kuhn, How China's Leaders Think (Singapore: Wiley, 2011), 22.

8. Zheng Shiping, Party vs. State in Post-1949 China (Cambridge: Cambridge University Press, 1997), 13.

9. Kenneth Lieberthal and Michel Oksenberg, Policy Making in China (Princeton, NJ: Princeton University Press, 1988), 403.

10. Andrew Mertha, "Fragmented Authoritarianism 2.0': Political Pluralisation in the Chinese Policy Process,” China Quarterly, no. 200 (2009): 996. 
of agenda items are diverse. A number of agenda items are initiated by the SCSC itself, while others are suggested by ministries and other agencies within the Partystate. We seek to open the black box of how this top-level process operates to better understand the workings of China's government.

For any governing institution, the need for advice, information, and wellworked options is continuous. To understand the process, we will disaggregate the operations of the SCSC by utilizing two sets of concepts. The first is the concept of the SCSC as an institution, operating according to sets of formal and informal rules. The formal rules provide the framework within which it must work. The informal rules include the standard operating procedures, the guidelines, and the expectations by which day-to-day business is managed. They are by no means immutable, but they shape the perceptions of all those involved. ${ }^{11}$

The second set of concepts are those of the core executive. Governing raises common challenges across political systems. The core executive seeks to identify the way central agencies work: how coordination is exercised depends on the resources and skills (informal rules) as much as on position (formal rules). In explaining the collective governing in Westminster systems, the core executive literature emphasizes that the power of coordination depends on who has the resources, rather than who holds the formal title or position. Therefore, "the full range of actors within the central government territory needs to be included" in studying the power of coordination or conflict resolution. ${ }^{12}$ It does not matter where they stand in the hierarchy; their contribution to central coordination depends on what resources they can bring to the table for that occasion, hence the stress on contingency. These resources can include: formal powers, staff, funding, access, information, control over communication, expertise, and even time. "They may increasingly be connected to the capacity to set agendas and define the alternatives at stake," as Poguntke and Webb note. ${ }^{13}$ They can involve personal characteristics or ability or can be institutional (e.g., supporting systems or organizational capacity). ${ }^{14}$ Such studies are useful to understand how coordination works

11. Douglas North, Institutions, Institutional Change and Economic Performance (New York: Cambridge University Press, 1990); Gretchen Helmke and Steven Levitsky, "Informal Institutions and Comparative Politics," Perspectives on Politics 2, no. 4 (2004): 37-55; Julia Azari and Jennifer Smith, "Unwritten Rules," Perspectives on Politics 10, no. 1 (2012): 725-40.

12. Robert Elgie, "Core Executive Studies Two Decades On," Public Administration 89, no. 1 (2011): 72. Elgie provides an excellent survey of this set of literature. See also Patrick Dunleavy and R. A. W. Rhodes, "Core Executive Studies in Britain," Public Administration 68, no. 1 (1991): 3-28; Thomas Poguntke and Paul Webb, eds., The Presidentialisation of Politics (Oxford: Oxford University Press, 2005).

13. Thomas Poguntke and Paul Webb, eds., The Presidentialisation of Politics (Oxford: Oxford University Press, 2005), 9. See also Patrick Weller, "Administering the Summit," in Administering the Summit, ed. B. G. Peters, R. A. W. Rhodes, and V. Wright (New York: Macmillan, 2000), 59-78.

14. Michael Smith, The Core Executive in Britain (London: Macmillan, 1999); R. Hefferman, "Prime Ministerial Predominance? Core Executive Politics in the UK," British Journal of Politics and International Relations 5, no. 3 (2003): 347-72. 
in the Chinese central government because they bring to our attention the powerful officials working at the secretariat of the SCSC who do not appear publicly and are not mentioned in the media but who work behind the scenes with a range of resources and capacities to make central coordination work. Only by including them can we appreciate the complexity of governing and assess the impact and standing of the State Council.

The core executive literature proposes a field for research but leaves open the precise formula that can be applied. Anyone advancing analysis needs to undertake extensive and detailed research to provide empirical evidence of who does what. Without that knowledge, it is impossible to answer the question of why.

\section{METHODOLOGY}

An effort to analyze the workings of the core executive in China starts at a disadvantage. There are no detailed accounts of the way the State Council works, who is involved, or what networks have access to it. This study is based on a number of sources: government websites, official newspapers, and other media sources that cover the workings of the SCSC. These include the agendas of SCSC meetings released the day after the meetings are held. This information is often regarded with scepticism; the assumption is that the Chinese government only tells what it wants the public to know and may even mislead. The SCSC's press releases, however, never pretend to be exhaustive; they explicitly confirm that other issues are discussed that are not included. That does not matter for our analysis. Cabinets in Western governments usually do not announce what items are discussed or by whom. Observers rely on "inspired leaks" to understand what they do. In this case, it seems reasonable to build what we can on the information provided by the SCSC.

Available comments by the premier and other officials reveal that there are often differences in opinion. Given the inability to interview the current premier, we have made use of the diaries of Li Peng, ${ }^{15}$ who served as premier for a decade from 1987 to 1998, and the collections of speeches, dialogues, and internal memoranda of another former premier, Zhu Rongji, ${ }^{16}$ who served from 1998 to 2003, for further evidence of the internal operations of the SCSC, especially its role in coordination and conflict resolution, and for illustrations of the premiers' frus-

15. Li Peng, Li Peng dianli riji, dianli yaoxianxin [Li Peng's diary: Electricity development needs to come first] (Beijing: Zhongguo Dianli Chubanshe, 2005), Li Peng huiyilu, 1928-1983 [Li Peng's memoir, 1928-1983] (Beijing: Zhongguo Dianli Chubanshe, 2014).

16. Zhu Rongji, Zhu Rongji on the Record: The Road to Reform, 1991-1997 (Washington, DC: Brookings Institution Press, 2013), Zhu Rongji Meets the Press (Oxford: Oxford University Press, 2011), Zhu Rongji jianghua shilu [Zhu Rongji's speeches] (Beijing: Renmin Chubanshe, 2011). 
tration as they sought to get leading officials to do what they were supposed to do. These insights were confirmed in three visits to Beijing for discussions in the academies and universities with people who sit on the perimeter of key decision forums.

\section{THE STANDING COMMITTEE OF THE STATE COUNCIL}

The State Council, like the central institutions in all governments, has operating rules and formal and informal procedures that decision makers must follow. As an institution, it creates expectations that must be met by its components-the government ministries and commissions. As David Lampton recently pointed out, China "has gone from being ruled by strongmen with personal credibility to leaders who are constrained by collective decision-making, term limits and other norms, public opinion, and their own technocratic characters," 17 and accordingly the procedures and processes of government become more important as a condition for understanding Chinese politics.

The governing structure in China is organized into major functional areas, the four broadest of which are Party affairs, government work, state security, and foreign affairs. ${ }^{18}$ The "government work" resides with the State Council, which consists of the premier, four vice premiers, five state councillors, ministers of 25 ministries and commissions, the minister of one special commission, the auditor general, and the general secretary of the State Council. All of China's provincial governments as well as the Hong Kong and Macao Special Autonomous Regions report directly to the State Council. Each minister heads a nationwide vertical bureaucratic hierarchy, with offices at each subordinate territorial level of administration. In addition, each provincial governor and each city and county leader heads horizontal organizations across all sectors and fields. This forms a complex grid of governing in China.

The executive of the State Council, the SCSC, is responsible to ensure full vertical (from center to locality) and horizontal (among all ministries and commissions) coordination. ${ }^{19}$ This challenge is complicated by the fact that China is the only geographically large country without a formal federal system. ${ }^{20}$ So each min-

17. David M. Lampton, "How China Is Ruled," Foreign Affairs 93, no. 1 (2014): 76.

18. Lieberthal Governing China, 215.

19. Fewsmith, China Today, China Tomorrow, 55.

20. We recognize the important role fiscal federalism has played in the whole reform process; see, e.g., Gabriella Montinola, Yingyi Qian, and Barry R. Weingast, "Federalism, Chinese Style," World Politics 48, no. 1 (1995): 50-81; Zheng Yongnian, De Facto Federalism in China (Hackensack, NJ: World Scientific, 2007). We argue that so long as there is not a constitutional division of power between the central and provincial governments, all division of power is negotiated. 
istry has a provincial office in every province that is accountable both to the Beijing headquarters and to the provincial governor.

There has been a gradual standardization and institutionalization of the succession of government leaders, including the premier of the State Council, in the sense that the premier serves a five-year term with a limit of two terms. ${ }^{21}$ But successions in China seldom involve total turnovers: The current premier, Li Keqiang, for example, was a vice premier of the previous government; so was his predecessor, Wen Jiabao. It means a newly appointed premier is unlikely to upend existing practices and traditions.

Since the full State Council meets only once or twice a year, the premier, vice premiers, and state councillors form an executive group, the SCSC, which is the real equivalent of the cabinet of Westminster systems. All laws to be considered by the National People's Congress must be recommended by and go through the State Council, and everything going through the State Council must be discussed and decided by the SCSC. It regularly interacts too with the Standing Committee of the Politburo. Occasionally the two bodies will issue joint documents, often in the form of "suggestions," on issues concerning both the Party and the government. Several times a year, they also jointly issue the highest and most important party-state decrees, called zhongfa (中发). This is the most important form of collaborative directive, with a greater potency than many legislated laws.

The size of the SCSC has varied over the past 60 years. Under Zhou Enlai from 1959 to 1975, there were 16 vice premiers. In the 1980s, there were between 18 and 25 members. Li Peng continued the tradition with a large 15-member SCSC. At the time when Kenneth Lieberthal and Michel Oksenberg developed the concept of fragmented authoritarianism in which "bureau politics" typified national governing in China, some of its members had a large degree of autonomy in managing their ministries while holding positions at the SCSC where they could represent their narrow interests. For instance, powerful ministers such as $\mathrm{Gu} \mathrm{Mu}$, Yao Yilin, and Kang Shi'en served simultaneously as vice premiers and state councillors. In those circumstances "bureau politics," rather than the pursuit of coordination to achieve unified policies, was inevitable. ${ }^{22}$

However, since 1998 the membership of the SCSC has become standardized at 10 -one premier, four vice premiers, and five councillors (one of whom acts as the general secretary). Only two still serve dual roles as members of the SCSC and

21. Lowell Dittmer, "Patterns of Elite Strife and Succession in Chinese Politics," China Quarterly, no. 123 (1990): 405-30; Joseph Fewsmith, China since Tiananmen (New York: Cambridge University Press, 2001); Cheng Li, ed., China's Changing Political Landscape (Washington, DC: Brookings Institution Press, 2008). 22. See Gu Mu Huiyilu [Gu Mu's memoir] (Beijing: Zhongyang Wenxian Chubanshe, 2009); Li Peng huiyilu. 
as ministers-the Ministers of Defence and of National Security. The others do not have direct clients or narrow constituencies; rather SCSC responsibilities are their principal government function. Each member has several portfolios to oversee:

Vice Premier

Zhang Gaoli

Liu Yandong

Wang Yang

Ma Kai

Councillor

Yang Jing

Chang Wanquan

Yang Jieshi

Guo Shengkun

Wang Yong
Executive vice premier, National Development and Reform Commission

(NDRC), housing, environment

Education, health, sports, science, family planning

Agriculture, commerce, trade

Finance, industries, transport, energy

General secretary of the State Council

Minister of Defense

Foreign policy

Minister of National Security, security, law

Industries, work safety, state-owned enterprises

Another feature of the current SCSC is that, whereas previously SCSC members spent most of their careers working in the central government, six of the 10 current SCSC members have had experience working in provinces or municipalities. Their better appreciation of the issues should make cross-region, crosssector coordination more readily achieved.

Previous Experience

Premier

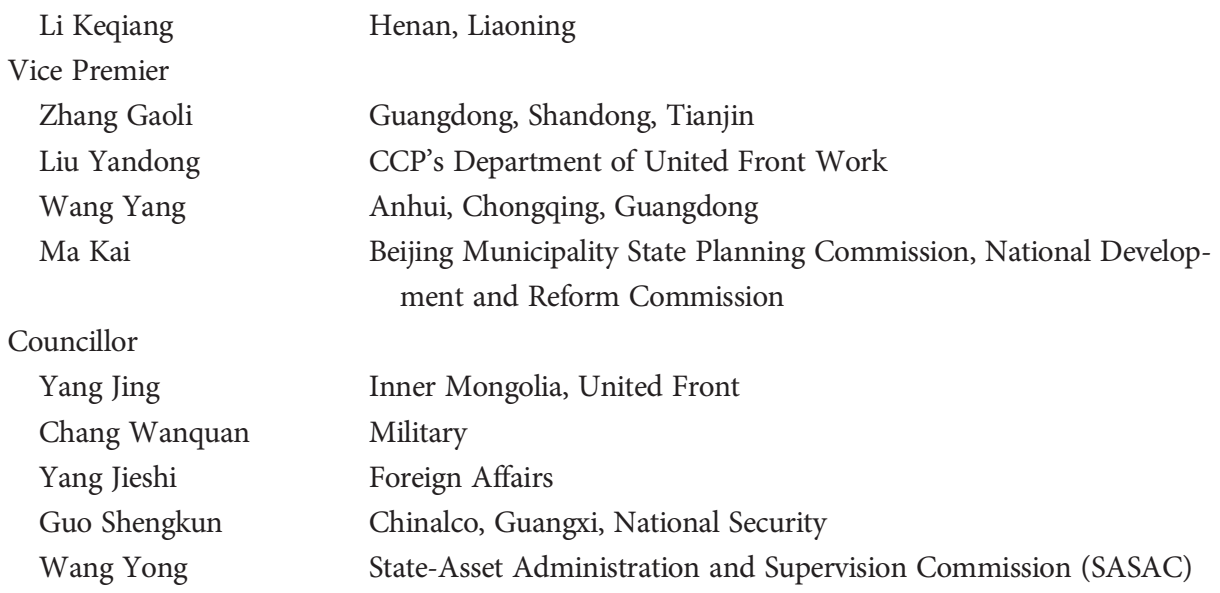

Finally, to emphasize the infused nature of the party-state in China, the premier is always at the core of decision making of the Party as a member of the Standing 
Committee of the Politburo. Currently, two SCSC members, the premier and his executive deputy, are among the seven members of the Politburo Standing Committee, and five (the premier and his four deputies) are among the 25-member Politburo. The SCSC and Politburo share the same secretary general. We can assume (even if no one except those in the inner sanctum can confirm) that there is constant communication between Xi Jinping as president and Party secretary and Li Keqiang as premier, in addition to their attendance at the Politburo Standing Committee meetings. The SCSC will never make important decisions that contradict those made by the Party, not least because the Party and the government work in an intertwined manner with this shared leadership. It is reasonable to assume ideas flow both ways, depending on the provenance and importance. The politics of the SCSC has to be understood in this context.

\section{PREMIERS SET THE TONE}

As with most cabinets, the style and priorities of the premier shape how the SCSC works. Zhao Ziyang "believed in expert advice and listened." Zhu Rongji's style "was to constantly ask probing questions and make observations." Both Zhao Ziyang and Wen Jiabao were "data and fact driven." ${ }^{23}$ Li Keqiang is "known as the master of detail, a strong manager," 24 and data driven too. Li Keqiang told a Chatham House audience, "You may not be interested in this, because I know think tanks are devoted to thinking, which is more abstract than the figures and mathematics, which looks more visionary and full of wisdom. But figures are the foundation. I'm not playing a game of figures. I just want to drive home my message." ${ }^{25}$

Reliance upon data means the premier has to be well serviced. His most important task is to coordinate the complex grid of ministerial bureaucracies and central, provincial, and local governments. Cooperation and coordination among officials from various government agencies are absolutely necessary for governing to work, and for serious problems to be averted. Governing China has become progressively more difficult with growing pluralization and diffusion of resources. Raw coercion does not work. The premier has to persuade ministers and governors of provinces, regions and municipalities to cooperate. This process of persuasion contradicts the common assumption that the top leaders in China always get what they want. As in so many other governments, premiers are often frustrated. Zhu Rongji is reported to have told his ministers, "My criticism is sometimes too severe and that is no good. But why do you have to wait until your leader

23. Lampton, Following the Leader, 60.

24. John Chipman, introduction to Chinese Premier Li Keqiang's keynote address, Chatham House, London, June 18, 2014.

25. Li Keqiang, keynote address, Chatham House, London, June 18, 2014. 
flies into a rage before starting to do your work? It's not that you can't do it, rather that you won't do it."26

Li Keqiang expressed similar frustration repeatedly at recent SCSC meetings. After listening to the inspection team he had sent out to provinces, he asked, "How can you still insist on your parochial interests and refuse to coordinate while globalization is already an international trend?" When told that some risk-averse officials refused to implement central policies, he told the SCSC meeting: "Those of you who don't do the job don't deserve your position; and unwillingness to take on responsibility is another form of corruption." 27 At an SCSC meeting in April 2015, Li harshly criticized his ministers: "It took us over a year to make a policy, and at various meetings all of you have already had your input. Now the policy is made and sent back to you to implement. Nothing has happened because some of your directors decided not to take any action on it. Don't you think it is ridiculous to let directors run the country?" After his outburst the State Council General Office issued an instruction requiring action be taken within 7 working days, or 10 if matters are complex. ${ }^{28}$ Zhu Rongji had made a similar complaint in March 1998, asking a minister, "How dare you allow your directors to run the country." He had sent out notices demanding action, but "low-level bureaucrats decided to ignore all the instructions, regardless from whom they are from, including mine." 29

The continuing frustrations over implementation undermines the argument that, as the Party controls the appointment, promotion, and rotation of all high ranking officials, the decision-making process and its outcomes all serve the interest of the Party and the state. ${ }^{30}$ Ministers and governors are not passive recipients of orders. They represent their specific institutions, are expected to promote and advance these narrow interests, and are judged by their performance. Making them do what the very top of the party-state has decided is always a challenge.

Reducing red tape was a priority for Premier Li. Nearly a year after he took up the position, it became clear that the ministries were resisting streamlining regulations and red tape. At one SCSC meeting, Li Keqiang pointed to a pile of documents and asked, "There was nothing to be approved under these procedures for eight years. Why do we still keep them on the books? . . Look at this item: one would need a license to negotiate business with foreign firms." Li then turned

26. Kuhn, How China's Leaders Think, 86.

27. Li Keqiang, "Zhengfu gongxinli she zhixingli de jichu" [Public trust rests on effective implementation], http://www.gov.cn/xinwen/2014-07/16/content_2718724.htm.

28. "Zonglimen tongpiguo naxieshi" [What was seriously criticized by premier], Zhongguo jiyejia [China entrepreneurs], May 3, 2015.

29. Zhu Rongji Jianghua Shilu 3 (2011): 29-36, 241-44.

30. Kjeld Erik Brødsgaard, "Politics and Business Group Formation in China," China Quarterly, no. 211 (2012): 624-48. 
to China's chief trade representative, the vice minister of commerce, and asked: "What does this entail? Have you had a license to negotiate on behalf of China?" Everyone laughed and the minister was embarrassed. "Now, you need to take the lead," Li continued, "to revolutionize yourself." 31 These frequent failures to deliver policies belie the notion that demands are implemented without question.

These exchanges reflect the universal and continuing problems of governinghow to ensure the lower levels of bureaucracies actually do what they are instructed-and also the tone and methods by which premiers can run their meetings. SCSC meetings, like cabinets in Western governments, are forums for decision more than discussion. Li and Zhu, like prime ministers, are impatient with meandering or self-congratulatory contributions and would cut short ministers who did not address the issue; there is no time for any but the most focused contributions. Not unlike Li Keqiang and Zhu Rongji, prime ministers often use the cabinet to ensure proposals are solid by cross-questioning ministers about the details; they deliberately keep ministers and officials nervous, even intimidated. Thatcher in Britain and Fraser in Australia were notorious for their inquisitorial style, which in their view provided a means of ensuring cabinet time was not wasted by illprepared ministers with inadequate proposals. ${ }^{32}$ SCSC meetings, like cabinets meetings, are working forums, not debating chambers.

Li Keqiang set rules for the SCSC that are similar to those in cabinets elsewhere. ${ }^{33}$ He told the SCSC that those scheduled to speak had no more than 10 minutes. He wanted them to report the key issues, identify the controversies, and any different suggestions; he did not want records of self-achievement, nor speeches from others that agreed with the proposal: "Premier Li looks quite nice and polite, but you need to be extra-prepared if you go to his meeting. He can interrogate and in detail." 34 That is a common role for heads of government.

31. "Li Keqiang: Fanghuo bushi fangren, guanhao bushi guangsi" [Li Keqiang: Streaming regulation does not mean there are no regulation; effective regulation does not mean tight control], June 4, 2014, http:// www.gov.cn/xinwen/2014-06/04/content_2693888.htm.

32. Patrick Weller, Malcolm Fraser PM (Melbourne: Penguin, 1989); Patrick Weller, Cabinet Government in Australia (Sydney: UNSW Press, 2007); Charles Moore, Margaret Thatcher, vol. 1, Not for Turning (London: Allen Lane, 2013); John Campbell, The Iron Lady (London: Vintage, 2012). Other prime ministers were far less polite than Li Keqiang in their treatment of their cabinet colleagues and officials. Stephen Harper, former prime minister of Canada, when frustrated, was known for his expletive-laden aggression. See, e.g., Paul Wells, The Longer I Am Prime Minister (Toronto: Random House, 2013).

33. It is not unreasonable to assume Li was well aware of cabinet practices. "In 2013, as Li Kequiang became the new Premier, it would be revealed that during the early 1990s, his wife, Cheng Hung, had translated the Yes Minister books into Mandarin (遵命大臣, 程虹译, 北京: 春风文艺出版社, 1991). It was said he was studying the volumes to prepare himself for dealing with his own country's obstructive civil servants." See G. McCann, A Very Courageous Decision: The Inside Story of Yes Minister (London: Arum, 2014), 293, citing South China Morning Post, October 30, 2012).

34. Lin Yan, "Jiedu guowuyuan changwuhui" [Understanding the Standing Committee of the State Council], Zhongguo Qingnian Bao, February 26, 2014, 12. 


\section{FUNCTIONS OF THE SCSC}

The State Council has been granted a series of responsibilities to govern the country. It has to:

- adopt administrative measures, enact administrative rules and regulations, and issue decisions and orders;

- assign tasks and responsibilities to ministries and commissions;

- decide the division of functions and authority between the central government and provinces, autonomous regions, and municipalities;

- draft and implement plans for national economic and social development;

- propose the state budget;

- approve the geographical division of provinces; and

- examine and decide the size of administrative organs. ${ }^{35}$

Its most important function is to coordinate the policies and actions of ministries and the policies of provinces and regions. Coordination has always been difficult in China.

The SCSC can have problems pushing through policies, due to diverse interests of provinces, localities, and ministries. ${ }^{36}$ Just before the current government assumed office, for example, Shanghai municipality government briefed the then executive vice premier, Li Keqiang, about the proposed initiative to open Pudong as a pilot special free-trade zone. For Li, the project could kick-start broader reform and spur growth when the Chinese economy was under downward pressure. Yet the initiative was opposed by four key institutions in the central government-the Ministry of Finance, China Banking Regulatory Commission (CBRC), China Securities Regulatory Commission (CSRC), and China Insurance Regulatory Commission. The CBRC and CSRC in particular made public their concerns about financial instability. After a long process to bring them on board, several rounds of explanations item by item, and a closed-door meeting where Li reportedly slammed the table, the SCSC finally approved the pilot project in principle in July 2013. ${ }^{37}$ Powerful government agencies and their officials can be serious obstacles to further reform and development. ${ }^{38}$

35. "Constitution of the People's Republic of China," http://www.npc.gov.cn/englishnpc/Constitution /node_2825.htm.

36. Dali Yang, Beyond Beijing (London: Routledge, 1997); Barry Naughton and Dali Yang, eds., Holding China Together (New York: Cambridge University Press, 2004); Pierre F. Landry, Decentralised Authoritarianism in China (Cambridge: Cambridge University Press, 2008).

37. Barry Naughton, “China's Economy," Daedalus 143, no. 2 (2014): 25; "Lingdaoren paian shike" [When leaders explode], Renmin Wenzhai, no. 6 (2014).

38. Yongshun Cai, "Managing Group Interests in China," Political Science Quarterly 129, no. 1 (2014): 107-31. 


\section{THE MANAGERIAL ORGANS OF THE SCSC}

What type of managerial support is provided to the premier and members of the SCSC? The form assistance takes will depend in part on whether the premier wants to develop a consensus, shape the policies, or oversee their implementation. Some require administrative support; others need both administrative and policy advisory capacity. The intent of the premier and his SCSC colleagues can be deduced from the presence and weight of their supporting institutions.

Three agencies warrant special attention: the General Office of the State Council (equivalent to the Cabinet Office in the UK or the Department of the Prime Minister and Cabinet in Australia), the Research Office of the State Council, and the premier's office. These are the key support staff working behind the scenes.

The General Office of the State Council is headed by the general secretary; he is one of the five councillors and also serves as the general secretary of the Politburo. This dual role provides a built-in mechanism to ensure cohesion in the policies of the Party and government. The General Office establishes the agenda for each SCSC meeting. This is not a simple administrative routine, as various ministers try to place their concerns on the agenda, so do many other players close to the helm of the party-state. Tradition dies hard-personal connections remain an important channel through which to squeeze things to the very top for decision. Yet the policy-making process has become much more standardized. Ministers bring issues to the attention of deputy premiers or councillors first, who then decide what can be raised at the SCSC. These matters can only be placed on the agenda with the approval of the premier. The formal procedure also requires ministers to send briefings to the General Office. ${ }^{39}$

The General Office provides procedural and advisory support. It assists the SCSC in managing daily affairs - it prepares agendas, drafts documents on behalf of the State Council, researches and suggests responses to issues raised by provincial governments, makes recommendations on issues where ministries disagree, and oversees the implementation of the State Council's decisions. The General Office issues documents that allocate formal authority for an issue, promulgates regulations, and provides information about binding decisions by the SCSC that apply across all ministries and provinces. These responsibilities go beyond what traditional civil servants can do. This is the reason that, among its 519 allotted positions, 53 are senior ranking officials, several at the minister and vice minister level. For example, each of the nine deputies of the General Office is accountable to a specific SCSC member. Among these nine individuals, three are at the rank of minster (one deputy to assist the premier, one to assist the vice-premier in

39. "Guowuyuan gongzuo guize" [The working procedures and rise of the State Council], adopted by the first session of the full State Council, March 20, 2013, http://www.gov.cn/zwgk/2013-03/28/content _2364572.htm. 
charge of national security, and one in charge of the daily business of the General Office). The other six deputies are at the vice minister level.

These deputies of the general secretary of the State Council increasingly are technocrats with extensive experience in various fields of the government. For example, the person designated to assist the premier, Xiao Jie, is a long-serving official at the Ministry of Finance, promoted to Vice-Minister of Finance in 2001; he was the director-general of the taxation department in 2007-13. Another deputy, Xiao Yaqing, made his reputation at the age of 40 when he turned a large loss-making SOE into one of the top 500 firms in the country in just two years and then created an international reputation in Chinalco's 2009 proposed acquisition of a substantial interest in multinational miner Rio Tinto. ${ }^{40}$ Another deputy, Jiang Xiaojuan, had established her reputation as a leading economist while working at the Chinese Academy of Social Sciences. Their experience and political rank give weight to their recommendations.

In sum, the deputies at the General Office of the State Council are not civil servants in the Westminster sense but neither are they traditional mishu (personal assistants or secretaries), identified by Lieberthal as political confidantes of political leaders. ${ }^{41}$ They are extremely senior professionals and experts in their own right, who have an independent standing in managing any issues assigned by the premier or the SCSC. These senior officials later are often promoted to lead ministries or become vice premiers, as in the case of Ma Kai. After a term as a deputy general secretary in the General Office, he became the minister of the National Development and Reform Commission (NDRC) and now is a vice premier. Several senior officials of the current government worked as deputies in the General Office too, including the current chair of NDRC, the finance minister, and the Party secretary of Fujian. This position prepared them for future roles at the centre of policy making in government.

While the General Office is in charge of managing all issues coming to the State Council, the Research Office of the State Council provides "private" policy support to the premier and the SCSC. The current head of the Research Office, Ning Jizhe (宁吉喆), had a similar career background as the premier-he was sent to the countryside during the Cultural Revolution, entered university in 1978, majoring in electrical engineering, and received his $\mathrm{PhD}$ in economics, before taking a position at the State Planning Commission and NDRC. Ning started working at the Research Office in 2003. In 2008-13 when Li Keqiang was the executive vice premier, Ning accompanied Li to nearly all meetings and consequently gained a reputation as his unofficial chief of staff.

40. Rebecca Mendelsohn and Allan Fels, "Australia’s Foreign Investment Review Board and the Regulation of Chinese Investment,” China Economic Journal 7, no. 1 (2014): 59-83.

41. Lieberthal, Governing China 2004, 211-15. See also Wen-Hsuan Tsai and Nicola Dean, "Lifting the Veil of the CCP's Mishu System," China Journal, no. 73 (2015): 158-85. 
The Research Office of the State Council was created in 1975 during a short period of stability ${ }^{42}$ amid the political turmoil of the 1970s and temporarily was abolished before resuscitation in its current form in 1988. It works only for the premier, his deputies, and the SCSC. It makes recommendations, writes their speeches, and most importantly, drafts the annual government report for the premier. Internal accounts suggest every single sentence proposed for that report is considered and reconsidered carefully; often at stake is not the substance of the policies but rather the worry is that the phrasing of terms can be interpreted in a variety of ways. ${ }^{43}$

One of the four deputies of the Research Office, Shi Gang (石刚), also heads the Premier's Office of about 30 people, including senior political advisers, personal assistants, and secretaries. Shi is a well-educated technocrat with a $\mathrm{PhD}$ in economics, who worked at economic analysis and forecasting for a decade and then macroeconomic policy analysis and state planning for various government agencies for another decade.

Crucially, the Research Office and the Premier's Office have direct access to the premier. They serve his interests, meet his demands, and are the principal people who see the world through his eyes. In their own words, "you need to know your leaders better than they know themselves." ${ }^{4}$

\section{THE WORK OF THE SCSC}

Meetings of central governing institutions such as the SCSC in some circumstances can either be core forums for discussion and decision making, or they can be rubber stamps. The best indicators of their roles are their routines, the existence of standing rules, the number of items on the agenda, and the seriousness with which members approach meetings.

The SCSC has a routine. It meets weekly on Wednesday mornings, nominally for half a day, although sometimes it drags on so that lunch has to be delayed. The list of items is released the next day. If Premier Li is away, meetings might be postponed until his return, as he is the only person with the authority to convene meetings. So when he went to an ASEAN meeting in Burma in November 2014, the Wednesday meeting was delayed until the next Saturday. ${ }^{45}$

Standard operating procures are needed to provide predictability. Members of a committee need to know what issues will be considered by whom and on the basis of what information. Effective processes cannot rely on whim or ever-

42. Ezra E. Vogel, Deng Xiaoping (Cambridge, MA: MIT Press, 2011).

43. Liu Bin, "Qicao lingdao jianghuagao dayou xunji" [Great skill needed to draft speeches for leaders], Renmin Wenzhai, no. 2 (2013).

44. Ibid.

45. See the list of SCSC meetings at http://www.gov.cn/guowuyuan/gwy_cwh.htm. 
changing criteria. Sometimes those rules may be informal, but at the higher levels of government in a complex modern world they need to be clear. That does not mean they have to be public; for decades cabinet systems in Britain and Canada were run on the basis of rules that were kept confidential.

The rules of the SCSC were promulgated by each premier when he first took office and thereafter were enforced and altered by the premier. At times he may choose to ignore them or bypass them. They are rules not laws. They are intended to bring order to the process, to ensure that issues coming to the SCSC are important, and that the members can be properly informed. At the very first meeting of the State Council of the current government, attended by all ministers and SCSC members, “The Working Procedures and Rules of the State Council” (国务院工作 规则) were approved. They emphasize the principle that the premier takes responsibility for the State Council's work, the importance of transparency, standardization, consultation, and effective implementation of policies. Fewer yet more efficient and effective meetings are promised. The Procedures require ministries and other government agencies under the State Council to "consult and coordinate" with each other on matters concerning more than one agency and report and get approval from the State Council on matters of "public interest." These exhortations may be serious if the premier wishes to enforce them. Most importantly, they highlight the current government's key priority to redefine the role for government, which in Barry Naughton's interpretation means the "government playing a reduced role in micro-economic decision making, the market playing a 'decisive role' in resource allocation, and the development of new models of social governance." ${ }^{6}$ This is where they differed from the working procedures and rules adopted by the previous government in 2008 .

The premier has the prerogative to decide what will be discussed at the SCSC and who attends. The nine members of the SCSC have to be present unless they have received permission for leave from the premier. ${ }^{47}$ There is no fixed number of people attending meetings. Ministers or their deputies with issues to defend will usually attend. The premier also invites representatives from firms, universities, or think tanks if he thinks they have something to contribute: it is his prerogative. Attendance at crucial meetings of bodies such as the SCSC is always sought eagerly. It is a sign of significance within any political system.

Ministers can only get their issues on the agenda through the General Office of the State Council and with the agreement of the premier. There is obvious competition for a place on an agenda limited to only a few items a week. These are often issues that cut across individual ministries' responsibility and thus need to be coordinated at the SCSC. Some items have to be tackled: pollution, for in-

46. Barry Naughton, “China’s Economy,” Daedalus 143, no. 2 (2014): 24; “Guowuyuan gongzuo guize.” 47. Ibid. 
stance, cannot be ignored; after an earthquake, a rescue and assistance plan has to be put in place; or job opportunities for university graduates, an annual discussion. Some may be items where the Standing Committee of the Politburo wants action and requires the SCSC to develop detailed policies. Some others will be pressing issues where a minister needs guidance and support. Items may come from above, from within, or from below.

By making the agenda public, Li opens up a window on the priorities of the government. The SCSC's meetings are forums to discuss, hear things out, and sometimes decide. Other times a meeting is used to check progress, and ministers send in reports and answer questions. This is particularly the case when a mediumand long-term plan in a specific sector is under review. These plans are issued as State Council documents. If the issues are about regulations or proposed legislation such as the nuclear energy law, telecommunication law, or food safety law, then SCSC approval may be the final hurdle in a long process. By the time the SCSC meets, some agreements among ministries and interests will have already been struck. Getting the draft through the State Council's Legislative Affairs Office is much more difficult than getting the support of the SCSC. ${ }^{48}$

The agenda is limited. For a weekly meeting, there are usually three or four main items on the agenda; the most within the most recent 18 months prior to our writing was seven. Ministers or their deputies come when their matters are under discussion and then leave. Because much of the preparation has been done in the ministries and the General Office, the meeting is reserved mainly for discussion and the premier's decision. That indicates a genuinely working committee, with each item being given time or space for discussion. An agenda of much greater size would suggest a rubber stamp.

We can identify the really contentious issues because they recur. For instance, streamlining regulations and procedures for business activities and changing the role of government in the economy were on the agenda of the very first SCSC meeting of the current government in March 2013. They were discussed at more than half of the SCSC's 56 meetings between March 2013 and July 2014. The difficulty was that those empowered to give the approval or issue licenses have refused to give up their power because many of the rules and regulations have been used for rent seeking. The recalcitrant include ministers. Other issues appear on the agenda repeatedly because details need to be worked out. Social security is one of them-for instance, how to provide a basic safety net in rural areas. Some confidential issues do not get publicly listed in the agenda.

The available documents allow us a peek at how ministers react at these meetings. Nowadays, ministers are restricted to no more than 10 minutes to brief the attendees. This is very different from the previous practices that "ministers talk,

48. Lampton, Following the Leader, 2014, especially chap. 3. 
talk and talk." Premier Li established the practice early on: "cut it short; I don't want to hear padded reporting; come to the point; what is the issue; and what is the problem." ${ }^{29}$ The ministers sometimes face tough questions. On February 12, 2014, for instance, one of the agenda items was how to deal with the worsening air pollution. The minister of environmental protection is not a member of the SCSC; he attended for his item and, following usual practice, left when the matter was dealt with. In this instance, after finishing his report, the minister stood up and was about to leave but was stopped by the premier, who asked a series of questions: "We've made policies on this or that issue, so why do we need new policies on them? Are the new measures well designed? How are you going to ensure that they will work? Have you done enough research on them?" Several other ministers helped answer the questions. One minister later commented: "Nowadays we need to be well prepared to come to his [the premier's] meetings." ${ }^{50}$ Keeping ministers and other senior officials on edge is one way to underpin his authority and shows he has to be satisfied that policies eventually get implemented.

Let us provide a simple example of the difficulty the SCSC has in seeking coordination of the activity of some of its powerful agencies. For some time, Chinese and foreign companies had complained that the national government's stateowned enterprises (SOEs) enjoyed an unfair advantage because they did not have to pay dividends. As the owner of these SOEs, the central government in principle agreed it should benefit from its assets. The question, however, was who would be in charge of collecting the dividends and who would control their spending. Two powerful institutions, the State-Asset Supervision and Administration Commission (SASAC), which is the State Council's special agency, and the powerful Ministry of Finance, fought for years over the rights. The battle was about empires, not policies. The issue was placed in front of the SCSC several times, requesting coordination and decision-making by the "cabinet." It was referred back to the ministries for more discussion and more coordination. ${ }^{51}$ The decision of the SCSC reflected the difficulty of governing, in mediating between two powerful agencies, each with a proper interest, and nether readily prepared to concede. It was a compromise-the Ministry of Finance would be in charge of collecting dividends while SASAC got control of spending the collected dividends.

49. Lin Yan, "Jiedu guowuyuan changwuhui" [Understanding the Standing Committee of the State Council], Zhongguo Qingnian Bao, February 26, 2014, 12.

50. Ibid.

51. See, e.g., World Bank, "SOE Dividends," Policy Note 56651 (2005); Unirule Institute of Economics, "Guoyou qiye de xingzhi: Biaoxian yu gaigei" [The nature, performance and reform of state-owned enterprises], April 12, 2012; Barry Naughton, "Claiming Profit for the State," China Leadership Monitor 18 (2006); Chen Mo, "The Framework of SOE Dividend Payment Emerges: Who Should Be in Charge of SOE Dividend Payment," China Economic Network, May 31, 2007; Li Rongrong, "Yangqi zerenxin dada tigao" [Improved responsibilities of SOEs], Xinhua News Network, December 19, 2006; World Bank, "Effective Discipline with Adequate Autonomy: The Direction for Further Reform of China's SOE Dividend Policy," Report Number 53254 (November 27,2009 ). 


\section{USE OF ALTERNATIVES STRATEGIES}

The SCSC is not the only route for such top-level government decisions. When the SCSC finds it too difficult to coordinate in a policy area, the premier can create interagency "leading small groups" (lingdao xiaozu) to manage and resolve domestic interagency, intersectoral, and interregional disputes or issues. The leading groups can be headed by a vice premier, with either ministers or their deputies as members. The groups do not have permanent personnel, budget, or offices. The premier or vice premier who leads the group decides which permanent agency manages the administrative work. For example, in 2013 the State Council formed a Farm Work Leading Small Group headed by vice premier Ma Kai, with the minister of Human Resources and Social Security as the key deputy. In this case, the Ministry of Human Resources managed the administrative and coordination work, which involved another 28 government ministries and agencies. ${ }^{52}$

On a number of important issues, the premier may chair a leadership small group. One such group is the National Energy Commission (NEC), created under Wen Jiabao in 2008, when energy security (mainly energy supplies) became not only a national but also an international issue. NEC was a high-level coordination body. At the time, NEC was seen as a sign that the government was about to form a mega-ministry on energy. Yet the efforts to coordinate interests among various energy sectors failed and the NEC met rarely. In July 2013 the NEC was strengthened, with the premier taking the chair and the executive vice premier as deputy; the rest were all ministers. This new NEC held its first meeting in April 2014 to discuss and endorse proposals for large hydro-projects, development of electrical vehicles, expansion of wind and solar capacities, and cross-region ultra-high-voltage transmission grids. ${ }^{53}$ In the end it is up to the National Energy Administration to come up with specific measures to implement these broad policies.

The meetings of these leading groups are irregular, depending on the schedule of the person who leads the coordination and the urgency of the issue. While the leading small groups' mission is to collect and exchange information and, most importantly, coordinate actions of all parts of the government, final decisions will have to be made at SCSC meetings, with the premier signing them off and the ministries implementing them.

Coordination can also take place when the premier chooses to consult with experts, such as scientists or business leaders or deputies of the National People's Congress. These meetings are held to exchange information, consult on policy

52. Compiled from the information provided under each member of the SCSC at the State Council and other government agencies' websites.

53. Li Keqiang, "Jiji fanzhan qingjie nengyuan, tuidong kaishan huanjing zhilian" [Active development of clean energy, promotion of environmental quality improvement], Chinese government website, April 20, 2014, http://www.gov.cn/guowuyuan/2014-04/20/content_2663208.htm. 
ideas, or reemphasize decisions. No formal decisions are made at such meetings, yet they are important for governing. For instance, in 2013-14 Li Keqiang held six separate meetings with business leaders from 26 different state-owned and private enterprises. Relevant ministers were invited to attend too, but they had to sit in the background. The invitees sat around the table with the premier and other members of the SCSC. In one of these meetings, when discussing the challenges that enterprises were facing, none of the invitees was willing to speak out. After being asked repeatedly, one reluctantly said, "Premier, this is your economic policy; how could we criticise it?" Another added, "How could we comment on policies in front of so many ministers?" But once started, conversation continued. ${ }^{54}$ The premier may also call together a group of economists from universities and government institutes to discuss the state of the economy or other issues. ${ }^{55}$ This is one way for the premier to find the pulse of the real economy and, more importantly, a way for him to "pressure" ministers to take actions on certain issues.

The premier may also call for meetings with governors of selected provinces and municipalities. These meetings are not held often but the premier usually has a clear agenda; the issues tend to be difficult and consultation is needed. ${ }^{56}$ Such meetings also sometimes bring pressure to bear to ensure that provinces and municipalities subjugate their local interests to broader ones and work out a coherent set of policies.

In sum, various forums are used to solicit ideas, develop options, facilitate compromises, or exert pressures. These meetings depend on initiatives of the premier with the support of his assistants. Like leaders everywhere, he can shift discussions to the forums where he finds the most useful debates or the greatest support for his own perspective. The significant point is that, whatever the vehicle he uses, the premier needs to gather options and support for government initiatives. These meetings are informal but critical not only for coordination and conflict resolution but for governing.

54. Li Keqiang, "Rang youzizhi de qiye douyou gongping jingzheng de jihui" [Fair competition for all qualified enterprises], Chinese government website, April 23, 2014, http://www.gov.cn/xinwen/2014-04/23/ content_2665335.htm; Qiyeja Cheng, “Buzhang zai buneng lun jianghua” [Enterprises claim, “we don't want to speak out in front of ministers"], July 15, 2014, http://news.sina.com.cn/c/2014-07-15/081430521100.shtml.

55. "Li Keqiang zai jingji xingshi zhuangjia zuotanhuishang qiangdiao jixu chuangxin hongguan tiaokong silu he fanshi" [Li Keqiang emphasizes the importance of continuing innovative thinking in macroeconomic management], Chinese government website, July 17, 2014, http://news.xinhuanet.com/fortune/2014-07/17/c_ 1111673571.htm; "Zhuanjia huiwei canjia Li Keqiang jingji zuotanhui xijie ganshou" [Experts discussed their attendance at the economic meeting hosted by Li Keqiang], July 21, 2014, http://www.gov.cn/xinwen/2014-07/ 21/content_2721387.htm; Yao Tongqin, “Zongli yu qiyejia keren tan le sha” [Premier meets entrepreneurs], China Economic Weekly, no. 4 (January 2014).

56. "Qiyeja cheng, 'buzhang zai buneng lun jianghua”" [Enterprises claim, we don't want to speak out in front of ministers], July 15, 2014, http://news.sina.com.cn/c/2014-07-15/081430521100.shtml; Lin Yan, "Jiedu guowuyuan changwuhui" [Understanding the Standing Committee of the State Council], Zhongguo Qingnian Bao, February 26, 2014, 12. 


\section{CONCLUSION}

This core executive analysis looks at how the SCSC operates at the top of government and suggests a complex picture of its role. The SCSC can be interpreted from several perspectives, just as cabinets in parliamentary democracies are. ${ }^{57}$

As a public policy forum.-The SCSC tries to determine public policy problems. It relies heavily on well-credentialed supporting agencies that are full of senior and experienced actors who see the world through the premier's interests. The premier will go back over issues, asking what has been achieved and how reasonable the demands are. Here the imperatives of politics and administration meet: how should the government act on a particular issue, what is it now doing, did it work? Although such questions will be asked while policies are being prepared, it is always with the knowledge that the premier might ask about the details and their practicality. Many of the issues are presented by ministries. Some others are passed on from the Standing Committee of the Party Politburo, putting into effect the Party's priorities. There is no single route or process.

As a bureaucratic regime.-The SCSC represents a government of routines. If once China, under Mao, was run in part on individual whim, it now has become an extensive government machine that requires leaders to secure consent and support. The SCSC's remit covers ministries, commissions, provinces, and an extensive array of SOEs. There is never enough time to consider everything. So the SCSC must be presented with proposals that tackle the big issues. The General Office, too often ignored by scholars, plays a significant role in establishing and policing routines to make the demands manageable. Sets of rules, now made public, determine how items will be organized. The premier's supporting offices give advice on how to deal with the challenges. Without rules and standard operating procedures to tame chaos, the SCSC could not work at all.

As a conciliator of political competitions.-All of the ministries, commissions, SOEs, and provincial governments have their own agendas and ambitions, and all cannot be satisfied. The SCSC at times acts as a funnel, concentrating attention and resources and arbitrating between demands. The government may be fragmented, but there have been attempts to ensure central priorities. Since fewer members of the SCSC now hold an additional position as a minister, they have a greater institutional interest to ensure that the SCSC acts effectively as the coordinator of government business. The fact that the SCSC and the Politburo Standing Committee have more than one shared member and a shared general secretary adds to this effectiveness.

As an institution with legitimacy and symbolic functions.-The SCSC stands at the helm of a network of institutions. It is the apex of the government machine,

57. Patrick Weller, “Cabinet Government: An Elusive Ideal?," Public Administration 81, no. 4 (2003): $701-22$. 
recognized in the Constitution. Much of the detailed work and many of the negotiations will take place earlier, within and among organizations that the SCSC oversees. The SCSC members must in turn undertake functions that are a challenge for any collective body at the head of government. There is really nothing surprising if the activities of SCSC reflect those of cabinets in democratic societies. Both struggle with similar demands. The problems they face seldom have simple answers that are somehow "correct." Rather, there are sets of big, enduring, and often uncomfortable puzzles. This is the collective problem that the centers of all big governments must manage: how to integrate ambiguous problems, competing demands, high expectations, inadequate information, and continuing social tensions, and to deliver administratively feasible and politically acceptable policies.

As part of a network. - The SCSC members participate in a series of networks that can assist. The premier is a member of the Politburo Standing Committee and chair of the SCSC; he convenes leading small groups or ad hoc meetings to find information, access expertise, encourage support and oversee the implementation of SCSC's decisions. This is not a picture of a command system, rather one of constant attempts to learn, persuade, encourage, cajole, and shame. ${ }^{58}$ Even when the Politburo Standing Committee decides, the premier needs to know who has the resources to deliver. He works through interlocking networks.

If this is indeed an accurate picture of the way that the SCSC works, it suggests a need to modify the dominant interpretations of the Chinese government, and particularly of the State Council, currently held by some China scholars. No doubt there are issues where the Politburo Standing Committee decides and the SCSC works within those boundaries. Even then, it is important to ask how the Politburo's wishes are fleshed out and implemented. In governing the country, the SCSC has its own decisions to make-and, given its responsibilities, important ones too.

Nor can the SCSC be reduced to its ministries or commissions. Ministers with hierarchies under them may be powerful in their own right, as the fragmented authoritarian model suggests, but they must work through the SCSC because it must struggle to balance priorities and to develop a consistent national policy framework. As Li Keqiang reminded his colleagues, ministers, and commissioners, they must work as a team. ${ }^{59}$

In short, the questions about how core executives coordinate initiatives, ensure consistency, facilitate agreements, oversee implementation, and possess the resources needed to achieve these ends are not exclusively relevant only to democratic regimes; they are problems of executive government. Using the insights of the Western core executive literature to understand how the SCSC op-

58. See Richard Neustadt, Presidential Power and the Modern Presidents (New York: Free Press, 1990).

59. Li Keqiang, "Zhengfu gongxinli she zhixingli de jichu" [Public trust rests on effective implementation], http://www.gov.cn/xinwen/2014-07/16/content_2718724.htm, "Li Keqiang: Fanghuo bushi fangren, guanhao bushi guangsi." 
erates strengthens the way we understand China's governmental policy making, because all coordinating core executives are faced with the same "collective problems": to set priorities, allocate time, gather the necessary information, tackle issues that have multiple possible solutions, and arbitrate where politics and administrative feasibility clash. The core executive must puzzle over ambiguous problems, competing demands, inadequate information, half-understood options, and recurring social tensions. Given the size of the polity, the difficulties of collective government need to be appreciated. We are not concerned here with how the players derive their legitimacy or how the views of policy recipients inform the process of governing, each of which are core concerns for democracies. Rather, by drawing attention to the similar collective governing dilemmas where ideology provides no specific answers, we can look beyond the differences in regime type to decipher the day-to-day operation of core institutions. 